\title{
Status of cattle insurance in select districts of Karnataka: A micro-economic study
}

\author{
GV Rohith ${ }^{1}$, PK Dixit ${ }^{1}$, M Sivaram ${ }^{1}$ and S Subash ${ }^{2}$
}

Received: 03 May 2019 / Accepted: 05 July 2019 / Published online: 28 October 2019

(c) Indian Dairy Association (India) 2019

\begin{abstract}
Livestock is one of the important productive assets in the rural areas in India which is most prone to many risk and uncertainties. This calls for an effective insurance mechanism for the farmers to cope with the household related shocks. In the view of scanty and sparse research studies on this vital issue, the present study derives the significance. The relevant data was collected from 240 dairy farming households comprising 80 sample households from each of the three districts namely, Kolar, Shivamogga and Dharwad of the Karnataka state were considered for the study. The sample was post-classified into insured and non-insured of cattle insurance. The study employed with descriptive statistics. In the study area, around 41 per cent of the farmers adopted cattle insurance, it was highest in Kolar (66.25 $\%)$ followed by Shivamogga (40.00 \%) and Dharwad (17.50 \%) and covered 18.48 per cent of milch animals, which was highest in Kolar (37.50 \%) followed by Shivamogga (14.02\%) and Dharwad $(9.46 \%)$ district. The majority of animals insured were crossbreds ( 86.42 to $87.50 \%$ ), followed by buffalo (8.33 to $10.00 \%$ ) and indigenous cattle (4.17 to $5.00 \%)$ across the districts. The mortality cases were higher in Shivamogga (42.52\%) but animal insured to total mortality percentage was only 16.67 per cent. The highest mortality cases indicating high risk were found in crossbreds (41.18 to $92.31 \%$ ) followed by indigenous (5.13 to $29.41 \%$ ) and buffaloes (2.56 to $29.41 \%$ ) across the districts. The claim settled to claim lodge percentage was highest at 91 per cent in Kolar district.
\end{abstract}

${ }^{1}$ Dairy Economics and Statistics, SRS of ICAR- National Dairy Research Institute, Bengaluru, India

${ }^{2}$ Dairy Extension, SRS of ICAR-National Dairy Research Institute, Bengaluru, India

PK Dixit ( $\square)$

Dairy Economics and Statistics, SRS of ICAR- National Dairy Research Institute, Bengaluru, India

E-mail:_drpkdixit@gmail.com
Keywords: Insured and non-insured cattle, Insurance coverage, Karnataka state, mortality, Socio- economic profile

\section{Introduction}

Livestock serves as security and poverty reduction means for majority of the marginal and small farmers in India. There are ample studies which portray that livestock is a liquid asset and livelihood support to the poor farmers particularly. The small and marginal farmers are generating about half of their income from livestock and the value of livestock representing a substantial percentage of farmers wealth, the death of livestock poses a considerable risk and affects the farmers net worth and income. In crops, the farmer may adopt risk efficient farm plans, grow less risky crops and can go for diversification of crops/ varieties. The possibilities of adopting these strategies in livestock sector are either non-existent or bleak. In such circumstance, the livestock insurance is one of the main risk mitigating strategies in this sector. The crop and livestock insurance offers a valuable means of protection to farm income against unavoidable risk and uncertainty, especially when used in conjunction with price supports, organized marketing, credit and extension facilities.

Livestock is one of the most important productive assets in the rural areas in India .But this vital asset is most prone to several risk and uncertainties. Hence, an effective insurance mechanism is essential for the farmers to cope with the household related risks. The policy makers are confronted with the challenges of bringing livestock assets of the resource poor under comprehensive risk cover but still very few farmers opt for livestock insurance as a risk mitigating strategy. Only 7 per cent of the cattle are insured (Sharma et al, 2010). Unless, there is compulsion from the lending agency, insurance is normally not adopted and there is also a mixed response on the undertaking of livestock insurance products. The study is more relevant keeping in mind the benefits of the livestock insurance especially, small and marginal farmers against any eventual loss to their animals. To contribute to the scanty literature on this important theme and to address the aforesaid issues, the proposed study was undertaken in select districts of Karnataka. Karnataka state is one of the progressive dairy states in Southern India, while, there is paucity of good research work on this vital issue. 


\section{Materials and Methods}

Karnataka state is divided into three distinct regions namely, Northern plain region, Malnad \& coastal region and Southern plain region based on topography, cropping pattern and animal production. The North Karnataka is dominated by buffalo, South Karnataka by crossbred and Malnad \& coastal region by indigenous cattle. Kolar, Shivamogga and Dharwad districts which represented the Southern, Malnad and Northern region of the state were selected for the study. Kolar district is having relatively maximum proportion of crossbred cattle population (1.73 lakhs) as compared to Shivamogga and Dharwad. Kolar district ranks first in terms of livestock insurance. These districts also represent the progressive dairy farming regions of Karnataka besides the good coverage of cattle insurance scheme and providing good background to the study. The sampling methodology adopted was multistage stratified random sampling. The eight villages were randomly selected from each of the selected districts. In the last stage of sampling, ten dairy farmers were selected randomly from each of the villages. Data was collected from a total sample of 240 dairy farming households comprising 80 dairy farmers from each district. The sample dairy farmers were further post- stratified into insured and non-insured categories on the basis of availing or otherwise of cattle insurance.

Tabular analysis: The data collected were presented in tables and used to study the profile of dairy animals insured and also to study the socio-economic profile of farmers who adopted cattle insurance. The socio-economic profile of farmers was analyzed with respect to age, education level, family size, herd size, land holding size, occupation pattern, kind of debt, and experience in dairying. The profile of the insured animals was analyzed with respect to breed, species, market price of animal, order of lactation, age, premium amount paid for the insured animal and sum insured. The simple averages and summations of the value were calculated and have been presented in tabular form for better understanding.

The claim lodged to animal insured and animal insured to total mortality percent were estimated by their respective ratios and multiplied with 100 for percentages. The mortality loss was worked out by product of number of died animals due to the disease and probable market value of the animal.

\section{Results and Discussion}

This paper describes the socio-economic background of the sample households, type of dairy animals being insured in the study area and the characteristics of the households who insured their cattle.

\section{Insured and non-insured sample households and comparison}

The numbers of farmers insured their cattle in the selected districts are present in Table 1. Of the total 240 sample households, 99 households $(41.25 \%)$ insured their animals. Majority of the farmers $(66.25 \%)$ insured their cattle in Kolar district followed by Shivamogga (40.00\%) and Dharwad (17.50\%). The farmers' awareness about cattle insurance was high in Kolar as there was more number of primary dairy cooperative societies $\&$ associated institutes and farmers were rearing high value crossbred animals specially HF which need protection in the form of insurance. Less number of animals were insured in Dharwad district where majority of the farmers reared more number of buffaloes and indigenous cattle.

\section{Socio-demographic characteristics of the sample farmers}

The general profile of sample farmers is depicted in Table 2. The results indicated that majority of sample farmers belonged to the age group of 41-60 years in both insured (39 and 46 per cent in Kolar and Shivamogga ) and non-insured (44, 58 and 42 per cent in Kolar, Shivamogga and Dharwad respectively) categories , while in Dharwad majority of insured farmers (57\%) belonged to the age group of $<40$ years. Percentage of farmers insuring the cattle belonged to the age group of $>61$ years was the least in all the three study areas. It was noticed that majority of farmers belonged to the small (upto 4) and medium (4-8) sized family category across the districts. About 47 and 43 per cent of the insured farmers fell into the medium sized family category (4-8) in both Shivamogga and Dharwad district. Where about 49 per cent of the insured farmers fell into small sized family category $(<4$ no.) in Kolar district. This was followed by medium sized family category in Kolar district (40\%). While, it was small sized family category in Shivamogga district (38\%). More than 90 per cent of the insured farm households was headed by male in all the three study areas (92\%, $94 \%$ and $93 \%$ ) in Kolar, Shivamogga and Dharwad respectively, while, in the case of non-insured category, it was 89,81 and 88 per cent, respectively.

In the case of education level, majority of the respondents had high school education both among the insured and non-insured farmers. About 74, 63 and 36 per cent of insured farmers and 59, 62 and 39 per cent of non-insured farmers possessed high school level of education in Kolar, Shivamogga and Dharwad respectively. The per cent of illiterate farmers was high in Dharwad as compared to Kolar and Shivamogga among insured category. Less than 15 per cent of the farmers possessed PUC and above level of education in both the insured and non-insured category in all study areas. About 60 per cent of the insured farmers belonged to small herd size category (1-3 no) in Kolar (66\%) and Shivamogga (60\%). Whereas, in Dharwad majority of the insured farmers belonged to medium herd sized category (42.86\%). Thus, it can be inferred that small and medium herd sized farmers are more inclined towards cattle insurance. Among non-insured farmers, majority of the farmer belongs to small herd sized category, this was highest in Kolar (88.89\%) followed by Dharwad (77.27) and Shivamogga (37.50). The insured and non-insured dairy farmers respondents were also classified according to their land 
holding. The results indicated that majority of the dairy farmers belonged to small and marginal land holding category in all the three districts. In the case of insured, majority of the farmers belonged to the marginal followed by small land holding category in all the three districts. Landless category was more in the case of non-insured farmers than insured farmers category. Similar findings was reported Subhash et al. (2016).

Experience in dairy farming is also one of the major factors influencing the behaviour of availing the cattle insurance. Majority of the insured farmers in Kolar (32\%) and Shivamogga (34\%) had 16-25 years of experience in dairying. In the case of Dharwad, majority $(35.71 \%)$ of the insured farmers had an experience of about 5-15 years in dairying. In case of non-insured farmers majority (25.50 to $42.42 \%$ ) of the farmers had an experience of 36 years and above in dairying. Farmers who availed the cattle loan, it was compulsory to insure the animals, so not even a single farmer belonged to loanee was under non-insured category.
Majority of the insured farmers in all the three districts did not avail cattle loan $(71 \%, 59 \%$ and $57 \%$ in Kolar, Shivamogga and Dharwad respectively. The sustained income from dairying is the reason for majority of farmers to belong under non-loanee category. Insured and non-insured dairy farmers were also examined for their membership. The results revealed that about 92,88 and 51 per cent of insured dairy farmers and whereas only 74,33 and 38 per cent of the non-insured dairy farmers were the members of dairy cooperative societies in Kolar, Shivamogga and Dharwad respectively. Membership in dairy co-operatives is a major driver to encourage the farmers to take up cattle insurance. Most of the farmers were following both crop farming and dairy farming as their occupation. It was 94,84 and 86 per cent for insured farmers and whereas 74, 81 and 80 per cent for noninsured farmers in Kolar, Shivamogga and Dharwad respectively. About 15, 8 and 15 per cent of non-insured farmer were following both agricultural labour and dairy farming in Kolar, Shivamogga and Dharwad, respectively. It is evident from the table 1 that, about 60,72 and 86 per cent of the farmers did not renew the cattle insurance. The renewal of the cattle insurance reveals the satisfaction level from clients and service delivery of the

Table 1 Distribution of sample farmers as insured and non-insured categories

\begin{tabular}{lllr}
\hline Districts & Insured & Non-insured & Total \\
\hline Kolar & $53(66.25)$ & $27(33.75)$ & $80(100.00)$ \\
Shivamogga & $32(40.00)$ & $48(60.00)$ & $80(100.00)$ \\
Dharwad & $14(17.50)$ & $66(82.50)$ & $80(100.00)$ \\
\hline
\end{tabular}

Note: Figures in the parentheses indicate percentages to the total

Table 2: General profile of the insured and non-insured farmers in select districts of Karnataka

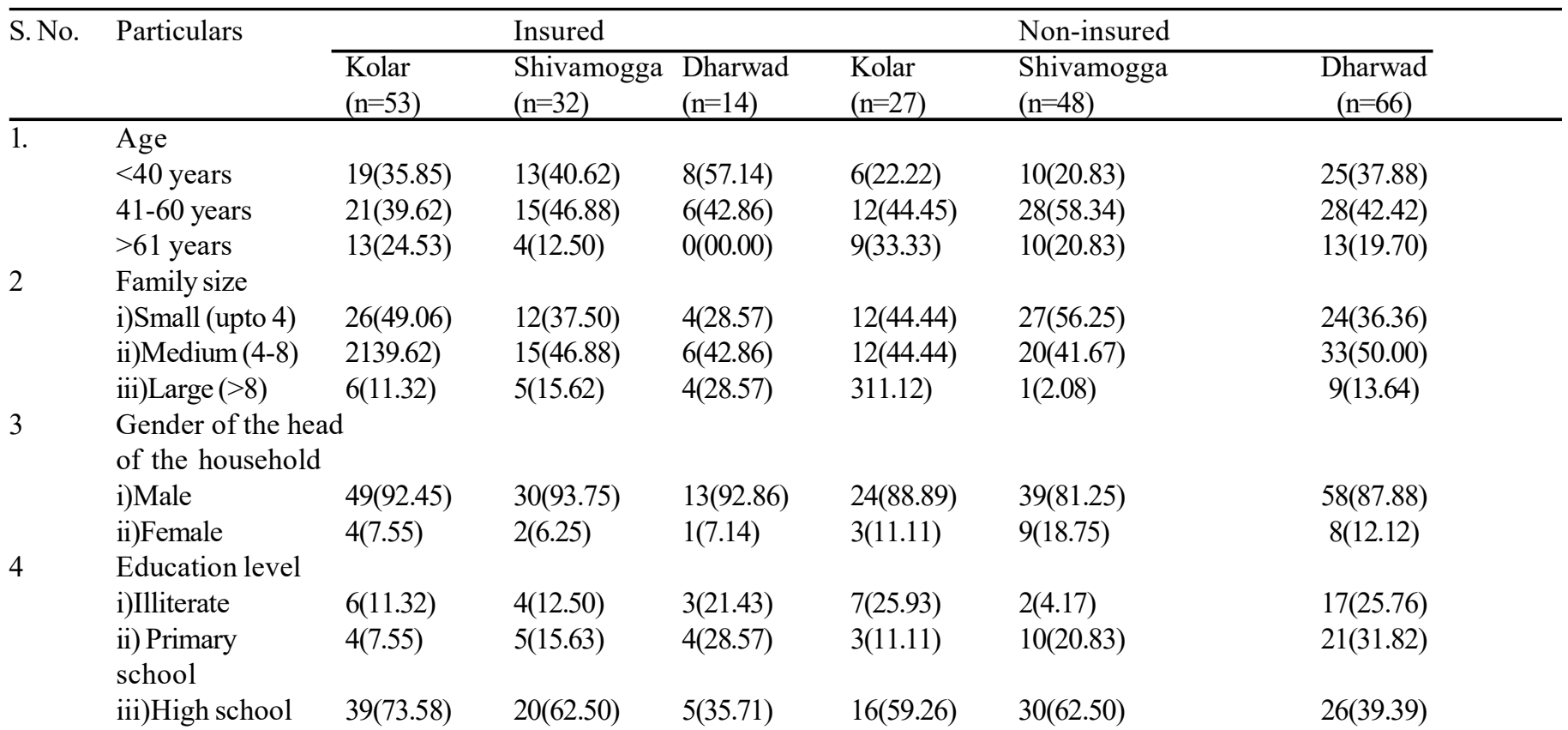




\begin{tabular}{|c|c|c|c|c|c|c|c|}
\hline & iv)PUC \& above & $4(7.55)$ & $3(9.37)$ & $2(14.29)$ & $1(3.70)$ & $6(12.50)$ & $2(3.03)$ \\
\hline \multirow[t]{4}{*}{5} & Herd Size & & & & & & \\
\hline & i)Small (1-3) & $35(66.04)$ & $19(59.38)$ & $5(35.71)$ & 24(88.89) & $18(37.50)$ & $51(77.27)$ \\
\hline & ii)Medium (4-5) & $12(22.64)$ & $4(12.50)$ & $6(42.86)$ & $2(7.41)$ & $15(31.25)$ & $9(13.64)$ \\
\hline & iii)Large $(>5)$ & $6(11.32)$ & $9(28.12)$ & $3(21.43)$ & $1(3.70)$ & $15(31.25)$ & $6(9.09)$ \\
\hline \multirow[t]{6}{*}{6} & Land holding size & & & & & & \\
\hline & i) Landless & $1(1.89)$ & $4(12.50)$ & $1(7.14)$ & $6(22.22)$ & $8(16.67)$ & $12(18.18)$ \\
\hline & $\begin{array}{l}\text { ii) Marginal } \\
\text { (<1 ha.) }\end{array}$ & $20(37.73)$ & $12(37.50)$ & $8(57.14)$ & $6(22.22)$ & $19(39.58)$ & $10(15.15)$ \\
\hline & $\begin{array}{l}\text { iii) Small } \\
\text { (1-2 ha.) }\end{array}$ & $19(35.86)$ & $9(28.13)$ & 2(14.29) & $6(22.22)$ & $12(25.00)$ & 19(28.79) \\
\hline & $\begin{array}{l}\text { iv) Medium } \\
\text { (2-4 ha.) }\end{array}$ & $8(15.09)$ & $4(12.50)$ & 2(14.29) & 518.52) & $5(10.42)$ & $15(22.73)$ \\
\hline & v)Large ( $>4$ ha) & $5(9.43)$ & $3(9.38)$ & $1(7.14)$ & $4(14.81)$ & $4(8.33)$ & $10(15.15)$ \\
\hline \multirow[t]{10}{*}{7} & $\begin{array}{l}\text { Experience in } \\
\text { dairying }\end{array}$ & & & & & & \\
\hline & $<5$ years & $6(11.32)$ & $2(6.25)$ & $2(14.29)$ & $4(14.81)$ & $6(12.50)$ & $4(6.06)$ \\
\hline & $5-15$ years & $15(28.30)$ & $11(34.38)$ & $5(35.71)$ & $4(14.81)$ & $12(25.00)$ & $7(10.61)$ \\
\hline & $16-25$ years & $17(32.08)$ & $11(34.38)$ & $4(28.57)$ & $7(25.93)$ & $12(25.00)$ & $15(22.73)$ \\
\hline & $26-35$ years & $10(18.87)$ & $2(6.25)$ & $2(14.29)$ & $4(14.81)$ & $6(12.50)$ & $12(18.18)$ \\
\hline & 36 years & $5(9.43)$ & $6(18.75)$ & $1(7.14)$ & $8(29.63)$ & $12(25.50)$ & $28(42.42)$ \\
\hline & $\&$ above & & & & & & \\
\hline & Cattle loan & & & & & & \\
\hline & i) Loanee & $15(28.30)$ & $13(40.63)$ & $6(42.86)$ & & & \\
\hline & ii)Non-loanee & 38(71.70.) & $19(59.38)$ & $8(57.14)$ & $27(100.00)$ & $48(100.00)$ & $66(100)$. \\
\hline \multirow[t]{9}{*}{8} & $\begin{array}{l}\text { Membership in } \\
\text { dairy cooperatives }\end{array}$ & & & & & & \\
\hline & i)Member & 49(92.45) & $28(87.50)$ & $7(50.50)$ & $20(74.07)$ & $16(33.33)$ & $25(37.88)$ \\
\hline & $\begin{array}{l}\text { ii)Non-member } \\
\text { Occupation }\end{array}$ & $4(7.55)$ & $4(12.50)$ & $7(50.50)$ & $7(25.93)$ & $32(66.67)$ & $41(62.12)$ \\
\hline & $\begin{array}{l}\text { i) Crop farming } \\
+ \text { dairy farming }\end{array}$ & $50(94.34)$ & $27(84.38)$ & $12(85.71)$ & $20(74.07)$ & $39(81.25)$ & $53(80.30)$ \\
\hline & $\begin{array}{l}\text { ii) Dairy } \\
\text { farming }\end{array}$ & $\mathrm{O}(0.00)$ & $2(6.25)$ & $\mathrm{O}(0.00)$ & $1(3.70)$ & $2(4.17)$ & $1(1.52)$ \\
\hline & $\begin{array}{l}\text { iii) Agricultural } \\
\text { labour + dairy farm }\end{array}$ & $\begin{array}{l}1(1.39) \\
\text { ling }\end{array}$ & $1(3.13)$ & $1(7.14)$ & $4(14.81)$ & $4(8.33)$ & $10(15.15)$ \\
\hline & iv) Crop farming & $2(3.77)$ & $1(3.13)$ & $1(7.14)$ & $1(3.70)$ & $1(2.08)$ & $1(1.52)$ \\
\hline & + dairy farming $+s$ & ervices & & & & & \\
\hline & $\begin{array}{l}\text { v) Dairy farming } \\
+ \text { services }\end{array}$ & $0(0.00)$ & $1(3.13)$ & $0(0.00)$ & $1(3.70)$ & $2(4.17)$ & $1(1.52)$ \\
\hline \multirow[t]{3}{*}{9} & $\begin{array}{l}\text { Renewal of cattle } \\
\text { insurance }\end{array}$ & & & & & & \\
\hline & i)Renewing & 21(39.62) & $9(28.13)$ & $2(14.29)$ & - & - & - \\
\hline & ii)Non renewing & $32(60.38)$ & $23(71.88)$ & $12(85.71)$ & - & - & - \\
\hline
\end{tabular}

Note: Figures in the parentheses indicate percentages to the total

insurance agencies. The reasons for non-renewal of cattle insurance as reported by dairy farmers were lack of trust on insurance scheme, lack of information about renewal procedure and irregular visits of the concerned stakeholders. Thus, there is a need to educate the farmers regarding the advantages of renewal and the procedure to be followed to renew the cattle insurance.

Milch animal species insured and non-insured in the study areas
The different kind of milch animals insured by farmers are depicted in Table 3. Totally 165 animals were insured out of 893 animals reared by 240 dairy farmers which accounted for 18.48 per cent of total cattle across the three districts. The highest number of animals were insured in Kolar (37.50 \%) followed by Shivamogga $(14.02 \%)$ and Dharwad $(9.46 \%)$ district. Of the total animals insured, insurance of crossbred cows occupied the prominent position with more than 85 per cent of the total animals in all 
three districts which was followed by the insurance of buffaloes. About 9, 10 and 8 per cent of total animals insured were buffaloes in Kolar, Shivamogga and Dharwad respectively. The reason behind the insurance of crossbred cow can be attributed to its high market value. It is quite evident that despite of many steps taken by the concerned agencies, only a small proportion of the animals were insured and this is a matter of concern, indicates the need for educating farmers regarding the benefits of cattle insurance.

\section{Profile of the dairy animals insured and non-insured in the study area}

The coverage of insurance for different kind of bovine species according to different attributes of animals like market value, kind of bovine and order of lactation is presented in Table 4.
Results indicated that, farmers insured milch animals, heifers and young animals. As obvious the numbers of milch animal insured was more ( $>80 \%$ in all the three districts) followed by heifers and is due to higher market value. Whereas, most of non-insured animal belonged to the category of milch animals (51, 64 and 63 per cent) and young (36, 26 and 25 per cent) in Kolar, Shivamogga and Dharwad respectively for the non-insured animals.

Most of animals insured had market value more than ₹ 45000 per animal which was highest in Kolar (62.96 \%) followed by Dharwad $(58.33 \%)$ and Shivamogga (46.67\%) districts. But, in the case of non-insured animals, most of the animal belonged to the category of ₹ $15000-30000$ in Kolar $(32.50 \%)$, ₹ $<15000$ in Shivamogga (36.41\%) and ₹ 30000- 45000 in the case of Dharwad (32.44\%). Related to attributes of milk yield of animal, most of animals were

Table 3 Different milch animal species insured in sample districts

\begin{tabular}{|c|c|c|c|c|c|c|c|c|c|c|}
\hline \multirow[t]{2}{*}{ Districts } & \multicolumn{3}{|c|}{ Insured } & \multicolumn{3}{|r|}{$\begin{array}{l}\text { Non- } \\
\text { insured }\end{array}$} & & & & \multirow{2}{*}{$\begin{array}{l}\text { Insured } \\
\text { /Grand } \\
\text { total } \\
(\%)\end{array}$} \\
\hline & $\begin{array}{l}\text { Indigenous } \\
\text { cow }\end{array}$ & $\begin{array}{l}\text { Crossbred } \\
\text { cow }\end{array}$ & Buffalo & Total & $\begin{array}{l}\text { Indigen } \\
\text { cow }\end{array}$ & $\begin{array}{l}\text { isCrossbred } \\
\text { cow }\end{array}$ & Buffalo & Total & $\begin{array}{l}\text { Grand } \\
\text { Total }\end{array}$ & \\
\hline Kolar & $\begin{array}{l}4 \\
(4.94)\end{array}$ & $\begin{array}{l}70 \\
(86.42)\end{array}$ & $\begin{array}{l}7 \\
(8.64)\end{array}$ & $\begin{array}{l}81 \\
(100.00)\end{array}$ & $\begin{array}{l}16 \\
(11.85)\end{array}$ & $\begin{array}{l}80 \\
(59.26)\end{array}$ & $\begin{array}{l}39 \\
(28.89)\end{array}$ & $\begin{array}{l}135 \\
(100.00)\end{array}$ & $\begin{array}{l}216 \\
(24.19)\end{array}$ & 37.50 \\
\hline Shivamogga & $\begin{array}{l}3 \\
(5.00)\end{array}$ & $\begin{array}{l}51 \\
(85.00)\end{array}$ & $\begin{array}{l}6 \\
(10.00)\end{array}$ & $\begin{array}{l}60 \\
(100.00)\end{array}$ & $\begin{array}{l}120 \\
(32.61)\end{array}$ & $\begin{array}{l}102 \\
(27.72)\end{array}$ & $\begin{array}{l}146 \\
(39.67)\end{array}$ & $\begin{array}{l}368 \\
(100.00)\end{array}$ & $\begin{array}{l}428 \\
(47.93)\end{array}$ & 14.02 \\
\hline Dharwad & $\begin{array}{l}1 \\
(4.17)\end{array}$ & $\begin{array}{l}21 \\
(87.50)\end{array}$ & $\begin{array}{l}2 \\
(8.33)\end{array}$ & $\begin{array}{l}24 \\
(100.00)\end{array}$ & $\begin{array}{l}40 \\
(17.78)\end{array}$ & $\begin{array}{l}116 \\
(51.56)\end{array}$ & $\begin{array}{l}69 \\
(30.67)\end{array}$ & $\begin{array}{l}225 \\
(100.00)\end{array}$ & $\begin{array}{l}249 \\
(27.88)\end{array}$ & 9.64 \\
\hline
\end{tabular}

Note: Figures in the parentheses indicate percentages to the total

Table 4 Profile of the dairy animals insured and non-insured in sample households

\begin{tabular}{|c|c|c|c|c|c|c|c|}
\hline \multirow[t]{2}{*}{ S.No. } & \multirow[t]{2}{*}{ Particulars } & \multicolumn{3}{|c|}{ Insured } & \multicolumn{3}{|c|}{ Non-inured } \\
\hline & & $\begin{array}{l}\text { Kolar } \\
(\mathrm{n}=81)\end{array}$ & $\begin{array}{l}\text { Shivamogga } \\
(\mathrm{n}=60)\end{array}$ & $\begin{array}{l}\begin{array}{l}\text { Dharwad } \\
(\mathrm{n}=24)\end{array} \\
\end{array}$ & $\begin{array}{l}\text { Kolar } \\
(\mathrm{n}=135)\end{array}$ & $\begin{array}{l}\text { Shivamogga } \\
(\mathrm{n}=368)\end{array}$ & $\begin{array}{c}\text { Dharwad } \\
(\mathrm{n}=225)\end{array}$ \\
\hline \multirow[t]{5}{*}{$\overline{1}$} & \multicolumn{7}{|c|}{ Market value (₹/animal) } \\
\hline & $<15000$ & $2(2.47)$ & $3(5.00)$ & $0(0.00)$ & $25(18.52)$ & $134(36.41)$ & $57(25.33)$ \\
\hline & $15000-30000$ & $12(14.81)$ & $13(21.67)$ & $4(16.67)$ & $44(32.59)$ & $92(25.00)$ & $62(27.56)$ \\
\hline & $30000-45000$ & $16(19.75)$ & $16(26.67)$ & $6(25.00)$ & $40(29.63)$ & $112(30.43)$ & $73(32.44)$ \\
\hline & $>45000$ & $51(62.96)$ & $28(46.67)$ & $14(58.33)$ & $26(19.26)$ & $30(8.15)$ & $33(14.67)$ \\
\hline \multirow[t]{5}{*}{2} & \multicolumn{7}{|c|}{ Milk Yield (lire/animal/day) } \\
\hline & $<6$ & $14(17.28)$ & $17(28.33)$ & $6(25.00)$ & $79(58.52)$ & $280(76.09)$ & $141(62.67)$ \\
\hline & 6 to 12 & $20(24.69)$ & $24(40.00)$ & $8(33.33)$ & $24(17.78)$ & $68(18.48)$ & $62(27.56)$ \\
\hline & 12 to 16 & $16(19.75)$ & $13(21.67)$ & $6(25.00)$ & $12(8.89)$ & $7(1.90)$ & $17(7.56)$ \\
\hline & $>16$ & $31(38.27)$ & $6(10.00)$ & $4(16.67)$ & $20(14.81)$ & $13(3.53)$ & $5(2.22)$ \\
\hline \multirow[t]{4}{*}{3} & \multicolumn{7}{|l|}{ Kind of Bovine } \\
\hline & Milch Animals & $69(85.19)$ & $48(80.00)$ & $21(87.50)$ & $69(51.11)$ & $236(64.13)$ & $142(63.11)$ \\
\hline & Heifer & $10(12.35)$ & $11(18.33)$ & $2(8.33)$ & $18(13.33)$ & $35(9.51)$ & $26(11.56)$ \\
\hline & Young(below & $2(2.47)$ & $1(1.67)$ & $1(4.17)$ & $48(35.56)$ & $97(26.36)$ & $57(25.33)$ \\
\hline \multirow[t]{4}{*}{4} & \multicolumn{7}{|c|}{ Order of lactation } \\
\hline & $<3$ & $28(34.57)$ & $26(43.33)$ & $11(45.83)$ & $87(64.44)$ & $223(60.60)$ & $145(64.44)$ \\
\hline & $4-5$ & $33(40.57)$ & $24(40.00)$ & $12(50.00)$ & $36(26.67)$ & $118(32.07)$ & $77(34.22)$ \\
\hline & Above 5 & $20(24.69)$ & $10(16.67)$ & $1(4.17)$ & $12(8.89)$ & $27(7.34)$ & $3(1.33)$ \\
\hline
\end{tabular}

Note: Figures in the parentheses indicate percentages to the total 
under the categories of milk yield of more than 16 litres/day among the insured animal in Kolar (38.27\%) while, it was 6 to 12 litre / day category in the case of Shivamogga $(21.67 \%)$ and Dharwad $(25.00 \%)$. Whereas, in the case of non-insured animal category most of the animals belonged to the milk yield of $<6$ litre/day and non-milk yielding category which was highest in Shivamogga (76.09\%) followed by Dharwad $(62.67 \%)$ and Kolar $(58.52 \%)$. Most of the insured animals (40 to $50 \%$ ) were in $4-5$ th order of lactation followed by less than $3^{\text {rd }}$ lactation in Kolar and Dharwad district. But in Shivamogga most of the insured animals were in $<3{ }^{\text {rd }}$ lactation. Most of the non-insured animals, fell under the category of $<3$ rd lactation that was 64,60 and 64 per cent in Kolar, Shivamogga and Dharwad. The loss from losing/death of the animal during 4-5 th lactation is high as the milk yield and market value of the animals are high during that period. This is the main reason for more number of animals insured to fall under 4-5 th lactation. Similar observations were made by Singh (2015).

\section{Insurance coverage and mortality of bovine species}

The coverage of insurance and mortality of bovine species are presented in Table. 5. Totally 127 mortality cases were noticed across the districts during the period from 2006-07 to 2017-18.

Table 5 Mortality cases and insurance coverage for bovine species

\begin{tabular}{|c|c|c|c|c|c|c|c|c|}
\hline \multirow[t]{2}{*}{ Districts } & \multicolumn{3}{|c|}{$\begin{array}{l}\text { Type of } \\
\text { animal }\end{array}$} & \multirow{2}{*}{$\begin{array}{l}\text { Total } \\
\text { mortality } \\
\text { (TM) }\end{array}$} & \multirow{2}{*}{$\begin{array}{l}\text { Claim } \\
\text { settled } \\
\text { (CS) }\end{array}$} & \multirow{2}{*}{$\begin{array}{l}\text { Animal } \\
\text { insured } \\
\text { (AI) }\end{array}$} & \multirow[t]{2}{*}{$\begin{array}{l}\text { CS/AI } \\
(\%)\end{array}$} & \multirow[t]{2}{*}{$\begin{array}{c}\mathrm{AI} / \mathrm{TM} \\
(\%)\end{array}$} \\
\hline & $\begin{array}{l}\text { Indigenous } \\
\text { Cow }\end{array}$ & $\begin{array}{l}\text { Crossbred } \\
\text { Cow }\end{array}$ & Buffalo & & & & & \\
\hline Kolar & $2(5.13)$ & $36(92.31)$ & $1(2.56)$ & $39(100.00)$ & 10 & 11 & 90.91 & 28.21 \\
\hline Shivamogga & a 14(25.93) & $36(66.67)$ & $4(7.41)$ & $54(100.00)$ & 5 & 9 & 55.56 & 16.67 \\
\hline Dharwad & $10(29.41)$ & 14(41.18) & $10(29.41)$ & $34(100.00)$ & 1 & 2 & 50.00 & 5.88 \\
\hline
\end{tabular}

Note: Figures in the parentheses indicate percentages to the total

Table 6: Mortality cases and insurance coverage for different milch animal species

\begin{tabular}{lllllllllc}
\hline $\begin{array}{l}\text { Type of } \\
\text { animal }\end{array}$ & $\begin{array}{l}\text { Claim } \\
\text { settled } \\
(\mathrm{CS})\end{array}$ & $\begin{array}{l}\text { Animal } \\
\text { insured } \\
(\mathrm{AI})\end{array}$ & $\begin{array}{l}\text { Total } \\
\text { mortality } \\
(\mathrm{TM})\end{array}$ & $\begin{array}{l}\mathrm{CS} / \\
\mathrm{AI} \\
(\%)\end{array}$ & $\begin{array}{l}\text { AI/ } \\
\mathrm{TM} \\
(\%)\end{array}$ & $\begin{array}{l}\text { Amount } \\
\text { claimed/ } \\
\text { animal }(₹)\end{array}$ & $\begin{array}{l}\text { Total } \\
\text { amount } \\
\text { claimed (₹) }\end{array}$ & $\begin{array}{l}\text { Total } \\
\text { mortality } \\
\text { loss (₹) }\end{array}$ & $\begin{array}{c}\text { Mortality/ } \\
\text { animal } \\
(₹)\end{array}$ \\
\hline $\begin{array}{l}\text { Indigenous } \\
\text { Cow }\end{array}$ & 2 & 3 & 26 & 66.67 & 11.54 & $19500(28.36) 38000(9.04)$ & $391444(9.86)$ & $15056(19.59)$ \\
$\begin{array}{l}\text { Crossbred } \\
\text { cow }\end{array}$ & 13 & 17 & 86 & 76.47 & 19.77 & $27769(40.38) 361000(85.85) 3212516(80.91)$ & $37355(48.60)$ \\
Buffalo & 1 & 2 & 15 & 50.00 & 13.33 & $21500(31.26) 21500(5.11)$ & $366667(9.23)$ & $24444(31.81)$ \\
\hline
\end{tabular}

Note: Figures in the parentheses indicate percentages to the total

Table 7: Causes for mortality and number of insurance claimed for milch bovine species

\begin{tabular}{lllc}
\hline Sl.No. & Causes & Mortality & Claimed settled \\
\hline 1 & $\begin{array}{l}\text { Medical disorders } \\
\text { (pyrexia, enteritis, bloat, myocardial infarction, mastitis, calf }\end{array}$ & $63(49.61)$ & $9(56.25)$ \\
& $\begin{array}{l}\text { scores , Oesophageal obstruction) } \\
\text { Gynecological disorders } \\
\text { (Dystocia, Retained fetal membranes) }\end{array}$ & $12(9.45)$ & $1(6.25)$ \\
3 & $\begin{array}{l}\text { Bacterial \& Viral diseases } \\
\text { (Foot \& mouth disease, Black quarter) }\end{array}$ & $15(11.81)$ & $1(6.25)$ \\
4 & $\begin{array}{l}\text { Accidental injuries } \\
\text { (Accidental/natural calamities, snake \& dog bite injuries, }\end{array}$ & $19(14.96)$ & $2(12.50)$ \\
poison intoxication) & & \\
& $\begin{array}{l}\text { Neoplastic diseases } \\
\text { (Neoplastic cancerous disease) }\end{array}$ & $5(3.94)$ & $1(6.25)$ \\
6 & $\begin{array}{l}\text { Miscellaneous /unknown disease } \\
\text { Total }\end{array}$ & $13(10.24)$ & $2(12.50)$ \\
& & $127(100.00)$ & $16(100.00)$
\end{tabular}

Note: Figures in the parentheses indicate percentages to the total 
Total mortality cases was highest in Shivamogga $(42.52 \%)$ followed by Kolar (30.71 \%) and Dharwad (26.77\%). In different bovine species, highest mortality was noticed in crossbred cattle followed by indigenous cattle and buffaloes. Mortality of crossbred was higher in Kolar (92\%) followed by Shivamogga $(67 \%)$ and Dharwad (41\%). This is due to the prevalence of more number of crossbred cattles in Kolar than Shivamogga and Dharwad. Similarly, the prevalence of more number of buffaloes in Dharwad resulted in highest mortality rate of buffaloes in Dharwad (29\%) than Kolar and Shivamogga. The ratio of claim settled to animal insured was highest in Kolar (90.91\%) district due to well progress of the insurance scheme than Shivamogga (56\%) and Dharwad (50\%). The animal insured to total mortality percent was also highest in Kolar $(28.21 \%)$ followed by Shivamogga (16.67\%) and Dharwad (5.88\%).

\section{Mortality and insurance claimed for milch bovine species}

The mortality cases and insurance coverage for different milch animal species is represented in Table 6 . The highest mortality cases observed in crossbred cows ( 86 no.) followed by lowest in case of indigenous cows ( 26 no.) and buffaloes ( 15 no.), in which 17 crossbreds, 3 indigenous cattle and 2 buffaloes were insured. Insurance was claimed for 13 crossbreds, 2 indigenous cattle and 1 buffaloes in the study areas between 2006-07 to 2017-18. The animal insured to total mortality ratio was 12,20 and 13 per cent in the case of indigenous cow, crossbred cattle and buffaloes, respectively. The highest mortality loss was noticed for crossbred cows ( $₹ 32,12,516$ ) followed by indigenous cattle (₹ 3,91,444) and buffaloes ( $₹ 3,66,667)$. This can be attributed to more susceptibility of crossbred cattles for diseases, have high market value, and also mortality cases. The average mortality loss per animal was highest for crossbred cow ( $₹ 37,355 /$ animal) followed by buffaloes ( $₹ 24,444$ per animal) and indigenous cows ( ${ }^{1} 15,056 /$ animal). The ratio of claim settled to animals insured was the highest for crossbred cattle $(77 \%)$ followed by indigenous cattle $(67 \%)$ and buffaloes $(50 \%)$. There is a huge difference in the ratio and it is high for crossbred cattle because the farmers constantly pursued the insurance agency and submitted all the necessary documents in time as the mortality loss was very high for crossbred cattle as compared to indigenous cattle and buffaloes.

\section{Causes for mortality and number of insurance claimed}

Causes for mortality and number of insurance claimed by dairy farmers are presented in Table 7. The major cause for the mortality of milch bovine species were medical disorders like (pyrexia, enteritis, bloat, myocardial infarction, mastitis, calf scores, oesophageal obstruction) [49.61\% ] followed by accidental injuries [14.96\% ](accidental/natural calamities, snake and dog bite injuries and poison intoxication) and bacterial and viral diseases such as F\& MD and Black quarter [11.81\% ]. The other cause for the mortality of the milch bovine species were gynecological disorders $(9.45 \%)$ like dystocia, retained fetal membranes; neoplastic diseases (3.94\%) and remaining 10.24 per cent account by miscellaneous/unknown diseases in the study areas (2006-07 to 2018-19). Of the different causes of mortality, claims settled was $56.25,12.50$ and 12.50 per cent for medical disorders, accidental injuries and unknown diseases, respectively. The similar observations were reported by Khan et al. (2014).

\section{Conclusions}

The coverage of cattle insurance is still very low and was around 18 per cent of total cattle population. So there is a need to put added effort by the insurance implementing agencies to increase the coverage. Farmers have more tendency to insure high yielding milch animals than low yielding milch bovines. Thus, deciding the premium rates depending on milk yield would help in acquiring more coverage of insurance. More enrollment of farmers in dairy cooperative society would lead to more cattle insurance coverage. Government should take initiative to provide better veterinary services to reduce mortality, as the mortality cases were high in study area and to make cattle insurance financially viable.

\section{Acknowledgements}

The institute scholarship to the first author provided by the ICARNational Dairy Research Institute, Karnal is gratefully acknowledged. The guidance of members of advisory committee is also acknowledged. We are very much thankful for the cooperation $\&$ help received from the organizations and the dairy farmers.

\section{References}

Ahuja V, Rajasekhar M, Ramalinga Raju (2008) Animal health for poverty alleviation: A review of key issues for India, background paper prepared for Livestock Sector Review of the World Bank.

Birthal PS, Jha AK (2005) Economic losses due to various constraints in dairy production in India. Indian J Anim Sci 75: 1470-1475

Bardhan D, Kumar S and Singh RK (2015) Delivery of animal healthcare services in Uttar Pradesh: Present Status, challenges and opportunities. Agric Econ Res Rev 28: 127-13

Chand S, Kumar A, Bhattarai M, Saroj S (2016) Status and determinants of Livestock Insurance in India: A micro level Evidence from Haryana and Rajasthan. Indian J Agric Econ 71: 335-346

Chhikara KS, Kodan AS (2012) National Agricultural Insurance scheme (NAIS) in India: An assessment. Manage Labour Stu 37: 143-162

Choudhury M, Srinivasan R (2011) A Study on insurance schemes of Government of India. Report submitted to National Institute of Public Finance and Policy, New Delhi

Khan MA, Chander M, Bardhan D (2017) Status of cattle and buffalo insurance scheme in Gorakhpur district, Uttar Pradesh. Indian J Dairy Sci 70: 112-115

Raju SS, Chand R (2008) A Study on the performance of National Agricultural Insurance scheme and suggestions to make it more effective. Agric Econ Res Rev 21: 11-19

Sharma A, Gupta A, Mohan J (2010) Livestock insurance: lessons from the Indian experience. Institute for Financial Management and Research, Centre for Insurance and Risk Management. Chennai, India

Singh SP, Chandel BS, Horo A (2016) Is that high claims plug widening of livestock insurance scheme? A case study of Haryana state. Indian J Econ Dev 12: 525-30 